The Strength and Ductility of $\mathrm{LI}_{2}-$ Based Intermetallics

Final report

Grant No. DE-FGO2-86ER45260

\author{
E.M.Schulson \\ Thayer school of Engineering \\ Dartmouth College \\ Hanover, NH 03755 \\ January 18,2002 .
}

DOE Patent Clearance Granted

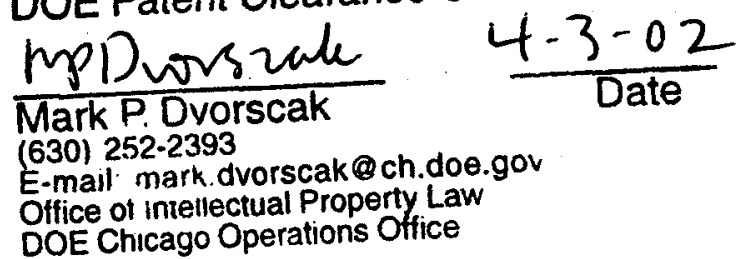

For the first time a complete and systematic study has been made of the strength and ductility of the $\mathrm{Ll}_{2}$-based intermetallic compounds $\mathrm{Ni}_{3} \mathrm{X}(\mathrm{X}=\mathrm{Al}, \mathrm{Ga}, \mathrm{Ge}, \mathrm{Ga})$, w/wo boron and $w /$ wo notches.Variables included grain size, boron concentration, deviation from stoichiomery, temperature ,strain rate, and notch geometry. Approaches included tensile, compression, hardness and Bauchinger tests; optical microscopy; scanning, transmission and high-resolution scanning-transmission electron microscopy; and numerical modeling. The hypothesis tested was that the increase in ductility induced by boron is caused largely by an increase in the accommodation of slip at grain boundaries. The results and interpretations were published in 41 papers (refs. below). Every result obtained over the course of the study is consistent with this hypothesis. Indeed, every result obtained by other investigators on the same alloy systems is also consistent with the hypothesis. Thus, we conclude the study by saying that the grain boundary accommodation of slip is a major factor in accounting for the beneficial effect of boron on the strength and ductility of $\mathrm{Ni}_{3} \mathrm{X}$-based $\mathrm{Ll}_{2}$ intermetallics.

\title{
Papers Published:
}

"Discussion of 'The Role of Boron in Ductilizing Ni $\mathrm{NII}_{3}$," E.M. Schulson, I. Baker and H.J. Frost, Met. Trans, 18A (1987), 1995-1996

"The Strength of $\mathrm{Ni}_{3} \mathrm{Al}$ Containing Titanium and Boron," S. Spear, G. Clothier, E.M. Schulson and I. Baker, Met. Trans. A, 19A (1988), 732-734 


\section{DISCLAMMER}

This report was prepared as an account of work sponsored by an agency of the United States Government. Neither the United States Goverament nor any agency thereof, nor any of their employees, makes any warranty, express or implied, or assumes any legal liability or responsibility for the accuracy, completeness, or usefulness of any information, apparatus, product, or process disclosed, or represents that its use would not infringe privately owned rights. Reference berein to any specific commercial product, process, or service by trade name, trademark, manufacturez, or otherwise does not necessarily constitute or imply its endorsement, recommendation, or favoring by the United States Government or any agency thereof. The views and opinions of authors expressed herein do not necessarily state or reflect those of the United States Goverameat or any agency thereof. 


\section{DISCLAIMER}

Portions of this document may be illegible in electronic image products. Images are produced from the best available original document. 
"The Effect of Boron on the Lattice Properties of $\mathrm{Ni}_{3} \mathrm{Al}$," I. Baker, B. Huang and E.M.

Schulson, Acta Met., 36 (1988), 493-499

"Microstructure of Extruded Ingots of $\mathrm{Ni}_{3} \mathrm{Al}$ Containing Boron." V. Zinoviev, E.M.

Schulson and I. Baker, Metallography, 21 (1988), 391-398

On Grain Boundaries in Nickel-Rich Ni3Al," I. Baker and E.M. Schulson, Scripta Met. 23 (1989), 1883-1886

"Auger Electron Spectroscopy Study of Ni3 Si," I. Baker, R.A. Padgett and E.M.

Schulson. Scripta Met., 23 (1989), 1969-1974

"On Grain Boundary Disorder and the Tensile Ductility of Polycrystalline Ordered Alloys: A Hypothesis," I. Baker and E.M. Schulson, Scripta Met. 23 (1989). 345-348

The Strength and Ductility of $\mathrm{Ni}_{3} S \mathrm{Si}$," E.M. Schulson, L.J. Briggs and I. Baker, Acta Met., $\underline{38}$ (1990), 207-213

"The Effects of both Deviations from Stoichiometry and Boron on Grain Boundaries in Ni3Al," I. Baker, E.M. Schulson, J.R. Michael, and S.J. Pennycook, Phil. Mag., B $62(1990), 659-676$

"Grain Boundary Chemistry in Ni3Al and Ni3Si," I. Baker, E.M. Schulson, J.R. Michael and R.A. Padgett, J. de Physique, Colloque C1, Tome 51 (1990), 77-82

"On Slip Transmission Across Grain Boundaries and the Brittle to Ductile Transition in Ni3Al and Other L12 Alloys," E.M. Schulson and I. Baker, Scripta Met. et Mater., 25 (1991), 1253 .

"The Yield Strength of Off-Stiochiometric Ni3 Al With and Without Boron," E.M.

Schulson, Y. Xu, P.R. Munroe, S. Guha and I. Baker, Acta Met. et Mater., 39 (1991), 2971-2975

"The Strength and Ductility of $\mathrm{Ni}_{3} \mathrm{Ge}$ With and Without Boron," J. Fang and E.M. Schulson, Mater. Sci. and Eng., A152 (1992), 138-145

"Formation of $\mathrm{Ll}_{2}$ Structured $\mathrm{Ni}_{3} \mathrm{Si}$," I. Baker, J. Yuan and E.M. Schulson, Met. Trans. A. 24A (1993), 283-292 
"Transmission Electron Microscopy in-situ Deformation Study of [111\} Zig-Zag

- Transgranular Cracks in the $\mathrm{Ll}_{2}$ Intermetallic Compound $\mathrm{Ni}_{3} \mathrm{Ge}^{\prime}, \mathrm{J}$. Fang and E.M.Schulson, Phil. Mag., A67 (1993), 1117-1127

"Effects of Strain Rate on Room-Temperature Tensile Properties of $\mathrm{Ni}_{3} \mathrm{Ge}+\mathrm{B}$ ", J. Fang and E.M. Schulson, Scripta Met., 31, (1994), 1307-1310

"Strength and Ductility of $\mathrm{Ni}_{3} \mathrm{Ga}$ With and Without Boron" Y.Xu and E.M.Schulson, Acta Metall et Mater. 43, (1995), 2121-2136

"The Dislocation Structure of $\mathrm{Ni}_{3} \mathrm{Ge}$ " J. Fang, E.M. Schulson, and I. Baker, Phil. Mag., 70. (1994), 1013-1025

"Strength, Hardness and Fracture Toughness of a Complex Nickel Silicide Containing Ductile Particles", Z. Li and E.M. Schulson, J.Mater Sci. 30 (1995), 2859-2865

"Dislocation Grain Boundary Interactions in $\mathrm{Ni}_{3} \mathrm{Ga}$ : In-Situ TEM Deformation", Y. Xu and E.M. Schulson, Scripta.Met.et. Mater. 33, (1995), 931-938.

"On the Notch Sensitivity of the Ductile Intermetallic Ni3Al Containing Boron," Y. Xu and E.M. Schulson, Acta Metall. et. Mater.,44, (1996), 1601-1612.

"Microstructures of Rapidly Solidified Powder and Extruded Rod of $\mathrm{Ni}_{3} \mathrm{Ge}$, J. Fang and E. M. Schulson, Materials Characterization, 37. (1996), 23-30.

"In-situ SEM Observations of Crack Nucleation and Propagation in Notched $\mathrm{Ni}_{3} \mathrm{Al}$," $\mathrm{Y}$. Xu, E. M. Schulson and M. Ignat, Scripta Mater., 36, (1997), 747-753.

"On the Ductility of $\mathrm{Ni}_{3} \mathrm{Al}$ : Effects of Strain Rate, Environment and Boron," E. M. Schulson and Y. Xu, Acta Mater. 45, (1997), 3491-3494.

"The Bauschinger Effect in Polycrystals of $\mathrm{Ni}_{3} \mathrm{Al}$ With and Without Boron," E. M. Schulson and Y. Xu, Phil. Mag. Letters, 76 (1997), 269-274. 
"A Comment on "Hydrogen-Boron Interaction and its Effect on the Ductility and Fracture of $\mathrm{Ni}_{3} \mathrm{Al}$, , E. M. Schulson, Scripta Mat., 38, (1998) 845-846.

"Notch-Tip Deformation of $\mathrm{Ni}_{3} \mathrm{Al}$ Single Crystals", E.M. Schulson and Y. Xu, Mat. Res. Soc. Symp. Proc., 1997, vol. 460, pp. 555-560, Dec. 2-6, 1996 in Boston, Massachusetts

"The Ductility of Stoichiometric and Ni-Rich Polycrystals of $\mathrm{Ni}_{3} \mathrm{Al}$ : The Effect of Strain Rate", E.M.Schulson and Y. Xu, Mat. Res. Soc. Symp. Proc., 1997, vol. 460, pp. 425-430, Dec. 2-6, 1996 in Boston, Massachusetts

"The Effects of Notches on the Deformation of Ductile Intermetallics", E.M. Schulson and Y. Xu, Proc. MRS. 364. (1995), 825-836

"The Notch-Embrittlement of Ductile Intermetallic Compounds", E.M. Schulson and Y.

$\mathrm{Xu}$ in "Fatigue and Fracture of Ordered Intermetallic Materials", ed. by W.O.

Soboyejo, T.S. Srivatsan and D.L. Davidson, TMS (1994) 87-102

"Interaction of Dislocations with Grain Boundaries in $\mathrm{Ni}_{3} \mathrm{Ge}$," J. Fang and E.M.

Schulson, Proc. EMSA, (1992), 172-173

"A Preliminary Study on the Behavior of Notched $\mathrm{Ni}_{3} \mathrm{Al}$ (B): Fracture Mode

Transition." Y.Xu and E.M.Schulson Proc. MRS (1993), 635-640

"The Fracture Toughness of A Brittle Nickel Silicide Containing the Ductile Phases $\mathrm{Ni}(\mathrm{Si})$ and $\mathrm{Ni}_{3} \mathrm{Si} ", \mathrm{Z} . \mathrm{Li}$ and E.M.Schulson, Proc. MRS, 288 (1993), 1081-1086

"\{111) Zig-Zag Cracking in Thin Foils of $\mathrm{Ni}_{3} \mathrm{Ge}$ ", J.Fang and E.M.Schulson, Proc. MRS, 288 (1993), 525-53

"Preliminary Indications of A Slight Improvement in the Ductility of $\mathrm{Ni}_{3} \mathrm{Ge}$ with Boron,". J. Fang and E.M. Schulson, Proc. Mat. Res. Soc. Symp., 213 (1991), $751-756$

"The Role of Slip Transmission Across Grain Boundaries on the Ductility of $\mathrm{Ni}_{3} \mathrm{Al}$ and Other L1.2 Intermetallic Compounds," E.M. Schulson, Proc. 6th Internat. Symp. on Intermetallic Compounds, Sendai, Japan, ed. by O. Izumi, Japan Institute of Metals (1991), 339-346 
"Decomposition of Ni-23 at.\% Si and Formation of $\mathrm{Ni}_{3} \mathrm{Si}_{1}$ " 1. Baker and E.M. Schulson, , Proc. 49th Annual Meeting EMSA San Francisco, CA (1991), 600

"Effect of Boron on the Composition of Grain Boundaries in $\mathrm{Ni}_{3} \mathrm{~A}$," I. Baker, E.M. Schulson and J.R. Michael, in Analytical Electron Microscopy (ed. D.C. Joy) (1987), 218-220

"The Ductility of $\mathrm{Ni}_{3} \mathrm{Al}$ and the Accommodation of Slip at Grain Boundaries," E.M. Schulson. I. Baker and H.J. Frost, Revue Phys. Appl. 23 (1988), 705

"The Strength and Ductility of Intermetallic Compounds," E.M. Schulson, I. Baker and H.J. Frost, in High-Temperature Ordered Intermetallic Alloys II, (eds. N.S. Stoloff, C.C. Koch, C.T. Liu and O. Izumi), Mat. Res. Soc. 81 (1987), 195-206

"Observations of Slip Propagation Across Grain Boundaries in $\mathrm{Ni}_{3} \mathrm{Al}$," I. Baker, E.M. Schulson and J.A. Horton, Proc. 44th Annual Meeting Electron Microscopy Soc. of America (1986), 864-869 